
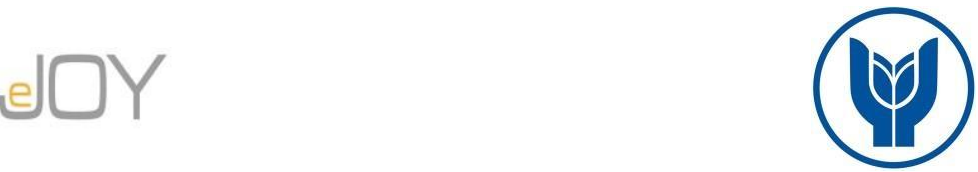

Kartal, M., T., Depren, Ö., Kılıç Depren, S. / Journal of Yasar University, 2019, 14/54, 180-195

\title{
Türk Bankacılık Sektöründe Psikolojik Taciz (Mobbing) Üzerine Bir Araștırma
}

\section{A Research upon Psychological Harassment (Mobbing) in Turkish Banking Sector}

\author{
Mustafa Tevfik KARTAL, Türkiye, mustafatevfikkartal@gmail.com \\ Özer DEPREN, Türkiye, ozerdepren@gmail.com \\ Serpil KILIÇ DEPREN, Yıldız Teknik Üniversitesi, Türkiye, serkilic@yildiz.edu.tr
}

\begin{abstract}
Öz: Küreselleşmenin yarattı̆̆ zorlu rekabet ortaml, iş hayatında önemli değişimlere neden olmaktadır. Bu bağlamda, iş hayatında çalıșanların karşı karşıya kaldıkları sorunlar da değişmektedir. Çalışanlar birç̧ok sorunla karşı karşıya kalmakla birlikte, bunların en önemlilerinden birisi psikolojik tacizdir. Bu çalı̧̧ma, Türk bankacıllı sektöründe önemli bir sorun haline gelen psikolojik tacizin araşstrılması amacını taşımaktadır. Bu amaçla 213 katılımcı ile anket çalışması yapılmıştır. Analiz sonucunda katılımcıların \%90,61'inin son 1 yıl içinde psikolojik tacize maruz kaldıkları belirlenmiştir. Ayrıca \%97,50 oranında kişilerin benlikleri ve \%66,88 oranında ülkedeki işsizlik psikolojik tacize neden olmaktadır. Katılımclların \%50'sinin psikolojik taciz sonucunda şikâyet etmeden çalışmaya devam ettikleri ve bankanın psikolojik tacize karşı tutumunun psikolojik tacizle mücadelede en önemli faktör olduğu belirlenmiştir. Çalışmanın en çarpıcı bulgusu ise psikolojik tacizle mücadelede rol alması beklenen iç denetim ve iç kontrol bölümlerinde dahi psikolojik taciz yașanmasıdır. Calıșa sonucunda, bankalarda psikolojik tacizin önlenebilmesi için psikolojik taciz vakalarının yönetim kurulu bünyesinde oluşturulacak etik komiteler tarafindan ele alınması önerilmiştir. Çalışmada belirtilen hususlar psikolojik tacizin önlenmesi konusunda bankalara yol gösterici olacakttr.
\end{abstract}

Anahtar Kelimeler: Bankacllk, Psikolojik Taciz, Faktör Analizi, Lojistik Regresyon, Türkiye

Abstract: The challenging competitive environment created by globalization causes significant transformation in business life. In this context, the problems, which employees have been facing, also have been changing. Although employees have been facing a variety of problems, one of the most important of them is mobbing. This study is prepared to research mobbing in Turkish banking sector which becomes an important issue. In order for this aim, a survey has been conducted on a sample of 213 participants. As a result of analysis, it is determined that $90.61 \%$ of participants were exposure from mobbing in the last one year. In addition, person's ego (97.50\%) and unemployment in the country (66.88\%) result in mobbing. Also, it is defined that $50 \%$ of participants continued to work without complaint and attitude of banks to mobbing is the most important factor in struggling with mobbing. It is the most shocking finding in the study that mobbing was seen in internal control and internal audit department which is expected to take place in struggling with mobbing. At the end of the study, dealing with mobbing cases by ethic committees to be established in the board of directors is recommended in order to prevent mobbing cases in banks. Issues stated in the study will guide to banks in preventing mobbing.

Keywords: Banking, Mobbing, Factor Analysis, Logistic Regression, Turkey

\section{Giriş}

Küreselleşme ve dijitalleşme ile birlikte yoğun değişim ve dönüşüm yaşanan iş hayatında çalışan haklarının korunması önemli bir husus olarak ortaya çıkmaktadır. İş hayatında çalışan haklarına yönelik tehdit ve tehlikeler zaman zaman farklı şekillerde görülmektedir. Günümüzde iş hayatında çalışanlara ve çalışan haklarına karşı yaygın şekilde görülen tehditlerin başında psikolojik taciz gelmektedir.

Bir grubun ya da bir kişinin hedef olarak seçilmiş kişiye/kişilere karşı sistematik, 1srarlı, hakir görücü, aşağılayıcı, yıldıııı, haksız söz ve davranışlar uygulaması psikolojik taciz olarak tanımlanmaktadır (Göktür ve Bulut, 2012). Bu tanımda belirtilen sistematik olma, bir kişiye yönelik yapılma vb. unsurlar psikolojik tacizin farklı kişiler ve kurumlar tarafından yapılan tanımlarında yer almaktadır. Genel olarak psikolojik taciz, çalışanlar üzerinde sistematik ve sürekli baskı yaratarak onları işten ayrılmaya zorlamak ve dolayısı ile tazminat ödeme yükümlülüğünden kurtulmak amacıyla işverenler tarafından uygulanmaktadır (Bozbel ve Palaz, 2007).

Psikolojik tacizin sistematik olması ve belirli bir süre devam etmesi çalışanların psikolojik ve fiziksel durumları üzerinde ciddi etkiler bırakmaktadır (Brigitte, 2004). Psikolojik tacize uğrayanlar çeşitli hastalıklar geçirmekte, fiziksel ve/veya psikolojik sağlıkları bozulmaktadır. Diğer taraftan psikolojik taciz, kurumlarda gerilimli ve çatışmalı bir örgüt kültürünün oluşmasına neden olan, çalışanların çalışma başarısını ve iş doyumunu olumsuz etkileyen örgütsel sorunlardan biridir (Tınaz, 2006).

Türkiye'de ekonomide yavaşlama ve daralma yaşanması ile birlikte bankacılık sektöründe psikolojik tacizin yaşandığına ilişkin internet ortamındaki yayınlar son zamanlarda artı̧̧ göstermektedir. Bu yayınlarda psikolojik taciz uygulayan ve uygulanan tarafların ve söz konusu bankaların isimleri belirtilmeksizin genellikle okuyucu mektubu şeklinde çeşitli olaylar paylaşılmaktadır. Yayınlardaki artış işçiler ve işverenler açısından psikolojik tacizin önemli bir husus olduğunu göstermektedir.

Psikolojik tacizin önlenebilmesi için hangi hususlarda yaşandığının tespit edilmesi gerekliliği ve bankacılıkta psikolojik tacize yönelik son zamanlarda artış gösteren yayınlar bu araştırmanın çıkış noktasını oluşturmaktadır. 
Mobbing'e karşılık olarak Türkçe' de birçok farklı terim kullanılmakla birlikte bu çalışmada psikolojik taciz karşılığının kullanılması tercih edilmiştir.

Bu çalışmada Türk bankacılık sektöründe psikolojik taciz konusu ele alınmıştır. Çalışma beş bölümden oluşmaktadır. Giriş bölümünden sonra ikinci bölümde psikolojik taciz kavramı, psikolojik tacizle mücadele yöntemleri ve psikolojik tacizle ilgili mevzuat incelenmiştir. Üçüncü bölümde literatür taraması kapsamında psikolojik tacizle ilgili bazı çalışmalar ele alınmıştır. Dördüncü bölümde Türk Bankacılık Sektörü (TBS) üzerine yapılan araştırma sonuçları ele alınmıştır. Son bölümde ise değerlendirme yapılmıştır.

\section{Psikolojik Taciz: Etkileri, Mücadele Yöntemleri ve Mevzuatı}

Psikolojik taciz, boyutu ve önemi geçmişte çok da bilinmeyen, özellikle işten ayrılan çalışanlar arasında sıklıkla görülen ancak günümüze kadar işletmelerde rekabetten kaynaklandığ düşünülen ve boyutu ve önemi yeterince fark edilmeyen bir olgudur (Tınaz, 2006). Psikolojik taciz farklı kişiler ve kurumlar tarafından değişik şekillerde tanımlanmaktadır. Psikolojik taciz "bir kişinin ya da bir grubun hedef seçilmiş kişiye karşı ısrarll, sistematik, aşă̆llayıcı, hakir görücü, yıldırıcı, haksız söz ve davranışlar uygulaması" olarak tanımlanmaktadır (Bayram, 2011). Sistematik olma, bir kişiye yönelik yapılma gibi unsurlar psikolojik tacizin farklı tanımlarında yer almaktadır. Bununla birlikte çalışanlar arasında görülen düşmanca ve uygunsuz her davranış psikolojik taciz olarak tanımlanamaz. Bu davranışların psikolojik taciz olarak nitelendirilebilmesi için sistematik bir süreç içinde kasıtlı bir biçimde kurgulanmış şekilde gerçekleşmesi gerekmektedir (Özen, 2007).

Psikolojik taciz sonucunda mağdur, önce kendisine, sonra çevresine karşı yabancılaşmaya başlar. Psikolojik taciz süreci, işe karşı bıkkınlık, kayıtsızlık ve performans düşüklüğü ile devam ederek işten ayrılma ile sonuçlanmaktadır. Bir başka ifade ile psikolojik taciz süreci kritik bir olayın meydana gelmesi ile başlar, psikolojik taciz davranışları ve damgalanma ile devam eder, yönetimin sürece katılması ile üçüncü aşama başlar, işten kovulma veya ayrılma ile son bulur (Güngör, 2008). Psikolojik taciz kişisel, kurumsal ve sosyal nedenlerden kaynaklanabilmektedir. Kişisel nedenlerin kapsamına kişilik yapısı, nitelikler, sosyal beceri; kurumsal nedenlerin kapsamına liderlik, örgüt kültürü, iş stresi, çalışma ortamı; sosyal nedenlerin kapsamına ise düşmanlık, kıskançlık, grup baskısı, günah keçisi durumları girmektedir (Çukur, 2012: 38). Leymann tarafından yapılan sınıflandırmaya göre psikolojik taciz, kişinin sağlığına, mesleki konumuna, itibarına, sosyal ilişkilerine ve iletişimine yönelik etkiler oluşturabilmektedir (Leymann, 1996).

Psikolojik taciz uygulayanlar, mağdurlar ve izleyiciler olmak üzere üç tarafi içermektedir. Psikolojik taciz uygulayanlar fesat, hiddetli, megaloman, sadist, korkak, eleştirici, hayal kırıklığına uğramış kişiler olabilmektedir. Psikolojik tacize uğrayan mağdurlar yalnız, farklı, başarılı, iş yerine yeni gelen kişiler olabilmektedir. Psikolojik taciz izleyicileri ise diplomatik, fazla ilgili, bir şeye karışmayan ve ikiyüzlü izleyiciler olabilmektedir (Tetik, 2010). Diğer taraftan psikolojik tacizin bazı işletmeler tarafından bir örgüt stratejisi olarak da kullanılabilmektedir. Ekonomide sorun yaşandığı dönemlerde küçülme sürecine giren işletmelerde personel sayısının azaltılması ilk tercih olup bu süreçte psikolojik taciz yaygın olarak başvurulan bir yöntem olmaktadır.

\subsection{Psikolojik Tacizin Etkileri}

Sistematik olarak bir süre devam eden psikolojik taciz, çalışanların psikolojik ve fiziksel durumları üzerinde ciddi olumsuz etkiler oluşturmaktadır (Brigitte, 2004). Psikolojik taciz mağdur açısından ekonomik ve sosyal zararlara, duygusal ve fiziksel zararlara neden olmaktadır. Psikolojik tacize maruz kalan bireylerde yaşam arzusunun kaybolması, ani öfkelenme, unutkanlık, alınganlık, ağlama krizleri, endişe, depresyon, halsizlik, sıkıntı, uykusuzluk, iştahsızlık, utanma, çekinme, korkma ve becerisizlik gibi bazı davranış ve düşünce değişiklikleri gözlemlenebilmektedir (Gökçe, 2009).

Psikolojik taciz, mağdurun yanı sıra işyerleri üzerinde de yıkıcı etkilere sahiptir. Psikolojik taciz kurumlarda gerilimli ve çatışmalı bir örgüt kültürünün oluşmasına neden olmaktadır. Bu nedenle çalışanların iş doyumu ve çalışma başarısı olumsuz yönde etkilenmekte, nitelikli işçilerin kaybedilmekte, çalışanların performans düşüklüğü nedeniyle verim kaybı yaşanmaktadır (Tutar, 2004). Psikolojik tacizin olduğu işyerlerinde kullanılan hastalık izinlerinde artış, tecrübeli çalışanların istifa etmesi nedeniyle işe alım ve eğitim maliyetlerinde artış, verimlilikte düşüş, davalar nedeniyle finansal maliyetlerde artış gözlemlenebilmekte, psikolojik tacizin işyeri dışında paylaşılmasıyla itibar riskine maruz kalma gibi durumlar yaşanabilmektedir.

Psikolojik taciz mağdurunun yaşadığı sıkıntıları ailesi ile paylaşması halinde söz konusu olumsuz psikolojik durumdan aile de etkilenecektir. Psikolojik taciz bir bütün olarak ele alındığında psikolojik taciz mağdurunu, ailesini ve işyerlerini ve dolayısı ile toplumu da olumsuz etkilemektedir. Sonuç olarak psikolojik taciz, hem kişilerin hem kurumların hem de toplumun sağlığını bozan örgütsel sorunlardan biri olarak karşımıza çıkmaktadır.

\subsection{Psikolojik Taciz Ille Mücadele Yöntemleri}

Psikolojik tacizin önlenebilmesi için en önemli husus mücadele yöntemlerinin bilinmesidir. Psikolojik tacizle mücadele yöntemleri bireysel, örgütsel, toplumsal seviyede olmak üzere üç bölüme ayrılır. Ayrıca hukuki mücadele yolu da bulunmaktadir.

Psikolojik tacize karşı bireysel mücadele kapsamında "tacizciyi ikaz etmek, rahatsız edici söz ve davranışlarını durdurmasını istemek; olayları, anlamsız emir ve talimatları yazılı olarak kaydetmek; psikolojik taciz durumunu çalışan 
Kartal, M., T., Depren, Ö., Kılıç Depren, S. / Journal of Yasar University, 2019, 14/54, 180-195

arkadaşlarıyla paylaşarak olaya şahit toplamak; tacizciyi ilk firsatta yetkili birine raporlamak; şikâyet/bildirim hakkında örgüt içinde ne yapıldı̆̆ını araştırmak; iş arkadaşları da rahatsı olduğunda grup halinde şikâyette bulunmak; sağllk durumlarl bozulduysa bunu doktor raporu ile belgelemek; psikolojik taciz katlanılamayacak boyutta ise sağlığı korumak için istifa etmek" faaliyetleri gerçekleştirebilmektedir (Aldığ, 2017).

Psikolojik tacize karşı örgütsel mücadele kapsamında "psikolojik tacizle mücadele için birimler oluşturulmal, bu birimlerin şeffaf ve adil biçimde işlenmesi sağlanmalıdır; çalışanların göre tanımları net sinırlarla belirlenmeli, çalışanlar görevlerinin ne olup olmadiğını bilmelidirler; kurum içi sosyal iliş̧ki ağları gelişstirilmelidir; kurumlar demokratik kurumsal kültür geliștirmeye çalıșmalıdır; kurumda psikolojik taciz konusunda bir farkindalık oluşturulmalıdır; örgütün disiplin konuları hızlı, tarafsız ve kalıcı nitelikte olmalıdır" faaliyetleri gerçekleştirebilmektedir (Erdem, 2014).

Psikolojik tacize karşı toplumsal mücadele kapsamında ise yazılı ve görsel kitle iletişim aracıları kullanılarak insanlara açıklama ve bilgilendirme yapılmalı, böylece bilinç oluşturulmalıdır. Diğer taraftan sendikalar psikolojik tacizle mücadelede önemli rol oynayabilirler.

Psikolojik tacize karșı mücadele kapsamında hukuki mücadele yolunun bulunduğu hiçbir zaman unutulmamalıdır. Kurum içi çözüm yolları tükendiyse veya bu yollarla çözüm bulunamıyorsa manevi tazminat davası açarak adli makamlara müracaat etme yolu da değerlendirilmelidir. Bununla birlikte ne yazık ki birçok ülkede psikolojik tacizle mücadele konusunda mevcut yasal düzenlemelerin yeterli olmadığı göz önünde tutulmalıdır (Sheehan, 2004).

\subsection{Psikolojik Taciz İle İlgili Mevzuat}

Avrupa Birliği'nde psikolojik tacizle ilgili özel düzenlemeler ilk kez İsveç’te yapılmıştır. "İşyerinde Şiddet ve Tehdidi Önlemeye İlişkin Kararname" ve "İşyerinde Mağduriyet Hakkında Kararname" 1993 yılında yayınlanmıștır. Bu kararnameler 1978 'de yürürlüğe giren Çalışma Ortamı Yasası'na istinaden çıkarılmıştır. Diğer taraftan 2008 yılında kabul edilen Ayrımcılık Yasası da psikolojik tacizle ilgili bazı hükümler içermektedir (Çukur, 2016).

Almanya'da psikolojik tacizle ilgili doğrudan ilişkili bir düzenlemeye rastlanmamıştır. Ancak 2001 yllında yürürlüğe giren İşyeri Örgütlenme Yasası, 2006 yılında yürürlüğe giren Eşit Davranma Yasası psikolojik tacize karşı dolaylı koruma sağlamaktadır. Diğer taraftan psikolojik tacizle ilgili mahkeme kararları bulunmaktadır. İlk mahkeme kararı 1997'de verilmiştir (Güzel ve Ertan, 2007). Amerika Birleşik Devletleri'nde psikolojik tacizle ilgili doğrudan ilişkili bir düzenlemeye rastlanmamıştır. Bununla birlikte 1964 tarihli Amerikan Yurttaş Hakları Yasası, 1967 tarihli İstihdamda Yaş Ayrımcılığı Yasası, 1970 tarihli Mesleki Güvenlik ve Sağlık Yasası, 1990 tarihli Engelli Amerikalılar Yasası psikolojik tacize karşı dolaylı koruma sağlamaktadır (Savaş, 2007).

Belçika'da psikolojik tacizle ilgili ilk düzenleme 2002 yılında İşyerindeki Şiddet, Psikolojik Taciz ve Cinsel Tacizden Korumaya İlişkin Yasa ile yapılmıştır. 1996'da çıkarılan İş̧in İcrasında Çalışanların Refahı Yasası ile bu yasada bazı düzenlemeler yapılmış ve psikolojik taciz konusunda ayrıntılı düzenlemelere yer verilmiştir (Poirier vd., 2018). Fransa'da ilk düzenleme 1992 yılında yapılmış, içeriğin sınılı olması ve yetersizliği nedeniyle 2002 yılında revize edilerek Sosyal Modernleşme Yasası yürürlüğe girmiştir (Güzel ve Ertan, 2007). Bu yasa ile Fransız İş Yasası ve Ceza Yasası'na manevi taciz kavramı adı altında psikolojik tacizle ilgili hükümler eklenmiştir (Bozbel ve Palaz, 2007). İngiltere'de psikolojik tacizle ilgili doğrudan bir düzenleme bulunmamaktadır. Ancak 1974 tarihli İşyerinde Sağlık ve Güvenlik Yasası, 1996 tarihli İstihdam Hakları Yasası, 1997 tarihli Tacizden Korunma Yasası ve 2010 tarihli Eşitlik Yasası psikolojik tacize karşı dolaylı koruma sağlamaktadır (ACAS, 2018).

Türkiye'de ise psikolojik tacizle ilgili düzenleme bulunmaktadır. Psikolojik tacizin önlenmesine ilişkin 2011 y1lında Başbakanlık tarafindan bir genelge yayınlanmıştır (Başbakanlık, 2011). İşyerlerinde psikolojik tacizin önlenmesi konulu genelge Türkiye'de psikolojik tacize ilişkin direkt hükümler içermektedir. Ayrıca Anayasa, Türk Medeni Kanunu, Türk Ticaret Kanunu, Türk Borçlar Kanunu (TBK), Türk İș Kanunu (TIKK) ve Türk Ceza Kanunu (TCK), psikolojik taciz ile ilgili dolaylı düzenlemeler barındırmaktadır. Adli makamlara intikal eden psikolojik taciz olaylarında mahkemeler konu ile ilgili olan Anayasa'nın eşitlik; TİK'in eşit davranma, iş sözleşmesinin feshi ve çalışma koşullarında değişiklik, iş̧̧inin haklı nedenle derhal fesih hakkı; TBK'nın iş̧̧inin kişiliğinin korunması; TCK'nın cinsel dokunulmazlık, hakaret, eziyet, iş ve çalışma hürriyetinin ihlali, tehdit, cinsel saldırı, cinsel taciz gibi hükümlerini dikkate alarak karar vermektedir.

\section{Literatür Taraması}

Literatürde yer alan bazı çalı̧̧malar psikolojik tacizi hukuki ve cezai yönden ele almıştır. Özkul ve Çarıkçı (2010), Türk hukuk sisteminde psikolojik tacize yönelik doğrudan bir düzenleme bulunmamasını büyük bir eksiklik olarak belirtirken, Taşkın (2015) psikolojik tacizle mücadele edilmesi için TCK'da ayrı bir suç olarak düzenlenmesi gerektiğini ifade etmiştir. Literatürde hangi tür çalışanların daha sık psikolojik tacize uğradığı konusu net değildir. Kimi çalı̧malar, psikolojik tacizin alt düzey çalışanlar ve kadınlar açısından önemli bir sorun olduğunu belirlemektedir (Kök, 2006; Göktürk ve Bulut, 2012). Bu çalışmaların aksine Cemaloğlu ve Ertürk (2007) ile Erçetin ve diğerleri (2008), psikolojik tacize uğrayan çalışanların büyük çoğunluğunun erkeklerden oluştuğunu belirlemişlerdir.

Literatürde bazı çalışmaların psikolojik taciz olgusunu, meslek grupları ve farklı değişkenler ile etkileşimi açısından ele aldığı görülmektedir. Şahin ve Türk (2010), kadın akademisyenlere yönelik yaptığı araştırmada, iş stresi ve iş performansları ile psikolojik yıldırma arasında ilişki bulunduğunu tespit etmiştir. Kaygın ve Atay (2014), Kars Aile ve Sosyal Politikalar İli Müdürlüğü’nde çalışanlara yönelik yaptığı araştırmada, örgütsel güven ile psikolojik taciz 
arasında negatif; örgütsel sessizlik ile psikolojik taciz arasında pozitif ilişki bulunduğunu tespit etmiştir. Turaç ve Şahin (2014), Ankara'daki beş hastanede çalışan hemşirelere yönelik yaptıkları araştırmada, hemşirelerin en fazla iletişim boyutunda psikolojik tacize maruz kaldıklarını, hemşirelerin \%68,5'ine yöneticileri tarafından psikolojik taciz uygulanmakta olduğunu ve hemşirelerin çalıştıkları bölümlere, toplam çalışma sürelerine ve yönetsel pozisyonlarına göre psikolojik tacize maruz kalma durumlarının farklılık gösterdiğini belirlemişlerdir. Bedük ve Yıldız (2016), Karaman ilinde sağlık çalışanlarına yönelik yaptığı araştırmada, örgütsel bağlılık düzeyi ile psikolojik taciz algıs1 arasında negatif yönlü bir ilişki olduğunu tespit etmiştir. Akpınar (2016), Diyarbakır ilinde öğretmenlere yönelik yaptı̆̆ı araştırmada, kadınlara kıyasla erkeklerin psikolojik tacize karşı daha etkili mücadele ettiği, yüksek lisans mezunlarının daha fazla psikolojik tacize maruz kaldığ 1 , kadın okul müdürlerinin olduğu okullarda psikolojik tacizle mücadeleye ilişkin puanların erkek okul müdürlerinin olduğu okullara kıyasla daha yüksek olduğu, evlilere kıyasla bekâr öğretmenlerin psikolojik taciz algısının daha yüksek olduğu sonuçlarına ulaşmıştır. Güngör ve Potuk (2018) ise öğretmenlerin psikolojik taciz davranışının tüm boyutlarında düşük düzeyde algıya sahip olduklarını saptamıştır.

Bazı çalışmalarda ise psikolojik taciz kişilere ve kuruluşlara etkileri açısından ele alınmıştır. Mercanlıoğlu (2010), psikolojik tacizin çalışma ortamının huzurunu, verimli çalışmayı, çalışanların fiziksel ve ruhsal sağlığını bozduğunu, böylece bireyleri, ailelerini ve toplumu olumsuz etkilediğini belirlemiştir. Altuntaş (2010), psikolojik şiddete uğrayan çalışanların, işyerlerinden uzaklaşmalarına karşın maruz kaldıkları psikolojik tacizin fiziksel ve ruhsal etkilerinden kurtulamadıklarını ortaya koyarak, psikolojik tacizin çok önemli bir yönünü ortaya çıkarmıştır. Bu sonuç psikolojik tacizin çalışanların sadece bugününü değil aynı zamanda geleceğini de etkilediğini ortaya koymaktadır. Atman (2012) ise psikolojik tacize maruz kalan kişilerin mutsuz bir iş ortamında çalışmak durumunda kaldığını, bu nedenle sağlıklarının ve işe odaklanmalarının bozulduğunu belirlemiştir. Çukur (2012). Psikolojik tacizden dolayı kişilerin psikolojik, fizyolojik ve ekonomik zarar gördüğünü ve psikolojik tacizin önlenmesi için yönetici konumundaki kişilere görev düştüğünü belirtilmiştir. Mizrahi (2013), psikolojik tacizin işverenlerin işten çıkarmak istedikleri çalışanlara tazminat ödemekten kurtulma amacıyla yapıldığ 1 ve psikolojik tacize maruz kalan kişilerin psikolojik zarar gördüğü sonuçlarına ulaşmıştır. Şimşek (2013) ise psikolojik tacizin iş yaşamını çekilmez hale getirdiğini ve çalışma ortamının huzurunu bozduğunu belirtmiştir.

Ayrıca literatürde psikolojik tacizin çeşitli hususlarla ilişkisini araştıran çalışmalar yer almaktadır. Dündar ve Acar (2008), çalışmalarında yaş ve pozisyon ile psikolojik tacize maruz kalma sıklığı arasında anlamlı bir ilişki bulunduğunu; cinsiyet ile psikolojik tacize maruz kalma sıklığı arasında ise anlamlı bir fark bulunmadığı sonuçlarına ulaşmışlardır. Demir ve Çavuş (2009) çalışmasında psikolojik yıldırma ile çalışanların iş stresi ve iş performansları arasında anlamlı bir ilişki bulunduğunu belirlenmiştir. Benzer şekilde Karcıŏlu ve Akbaş (2010), iş tatmini ile psikolojik şiddet arasında ters yönlü bir ilişki bulunduğunu tespit etmişlerdir. Tetik (2010), psikolojik tacizin çalışanlarda işten ayrılma eğilimine neden olduğunu, örgütsel bağlılığı azalttığını ve iş gören devir hızını artırdığını belirlemiştir. Karahan ve Yılmaz (2014), psikolojik tacizle örgütsel bağl1lık arasında ilişki bulunduğunu tespit etmişlerdir. Seçkin ve Demirel (2014), psikolojik yıldırma ile örgütsel adalet arasında orta düzeyde ilişki bulunduğu tespit etmişlerdir.

Yukarıda belirtilen konuların yanı sıra psikolojik tacizin önlenmesi ile ilgili çalışmalar da yapılmıştır. Yücetürk (2012), işyerlerinde yıldırma eylemlerinin önlenmesinde sendikalar önemli bir rol alabilecek iken sendikaların yıldırma eylemlerinin sebeplerinden biri olduğunu belirlemiştir. Temizel (2013), akademisyenlerin, hukukçuların, sendikaların ve meslek örgütlerinin bir arada hareket etmesiyle psikolojik tacizin azaltılabileceğini belirlemiştir. Pehlivan (2015) tarafından yapılan çalışmada ise psikolojik tacizin çığ gibi büyüme potansiyeline sahip olduğu, ayrıca psikolojik tacizin önlenmediği takdirde ekonomik suç oranlarında artışa neden olabileceği belirtilmiştir. Psikolojik tacizin önlenmemesinin psikolojik tacizi büyütme potansiyeli taşıdığının belirlenmesi açısından bu çalışma oldukça önem taşımaktadır.

Literatürde yer alan mevcut çalışmalar arasında Türk bankacılık sektöründe psikolojik tacizin araştırılmasına yönelik bir çalışma bulunmadığı belirlenmiştir. Bununla birlikte literatürde yer alan çalışmalar topluca değerlendirildiğinde, nedenler ve etkiler (hukuki, cezai ve meslekler üzerindeki etkiler vb.), önlenme, bazı hususlarla ilişki araştırması gibi açılardan psikolojik taciz ele almıştır. Dolayısı ile bu çalışmanın, Türk bankacılık sektöründe psikolojik tacizin araştırılması suretiyle literatüre katkı sağlayacağı değerlendirilmektedir.

\section{Türk Bankacılık Sektöründe Psikolojik Taciz Üzerine Bir Araştırma}

\section{1. Çalışmanın Amacı ve Yöntemi}

Bu çalışmada TBS'de psikolojik tacizin araştırılması, psikolojik tacizin yoğunlaştığı hususların belirlenmesi ve mevcut durumun analiz edilerek öneriler geliştirilmesi amaçlanmıştır. Sonrasında ise bireylerin psikolojik tacizle mücadele etme gücünü etkileyen faktörlerin neler olduğunun incelenebilmesi için lojistik regresyon modeli kurulması amaçlanmıştır. Fakat anketteki soru sayısının fazla olması ve ifadeler arası ikili korelasyonların yüksek olması sorununun önüne geçebilmek adına öncelikle faktör analizi uygulanarak kavramsal anlamlılığa sahip daha az sayıda bağımsız yeni faktörler belirlenmesi amaçlanmıştır. Bu sebeple ilgili analiz hipotezlerine Bölüm 4.3.3'te verilmiştir. Literatürdeki çalışmalarda kullanılan soru formları gözden geçirildiğinde, bireylerin psikolojik tacizle mücadele gücü üzerinde etkili olabileceği düşünülen faktörler belirlenerek Ek-1'deki soru formu oluşturulmuştur. Araştırılan konu özelinde daha önce herhangi bir ölçek belirlenmediği için bu çalışmada daha önce hazırlanan bir ölçek kullanılamamıştır. Bu çalışma Türk bankacılık sektöründeki psikolojik tacizle ilgili durumu analiz edebilmek amacıyla 
Kartal, M., T., Depren, Ö., Kılıç Depren, S. / Journal of Yasar University, 2019, 14/54, 180-195

yapıldığ için bankaların şube ve genel müdürlüklerinde çalışan veya daha önce çalışmış olan kişilere Surveymonkey üzerinden rassal olarak anket gönderimi yapılmıştır. Anket çalışması toplam 213 kişinin katılımı ile tamamlamıştır.

\section{2. Çalı̧smanın Betimleyici İstatistikleri}

Araştırmada katılımcıların cinsiyeti, eğitim düzeyi, çalıștı̆̆ı banka türü ve diğer sorulara ait bilgiler alınarak betimleyici istatistikler elde edilmiştir. Toplamda 213 katılımcının ilgili sorulara verdikleri yanıtların dağılımına Tablo 1'de yer verilmiştir.

Tablo 1. Katılımcıların Demografik Özelliklerine Ait Betimleyici İstatistikler

\begin{tabular}{|c|c|c|c|c|c|c|c|}
\hline Özellik & Detay & Frekans & $\%$ & Özellik & Detay & Frekans & $\%$ \\
\hline \multirow{3}{*}{ Cinsiyet } & Erkek & 106 & 49,77 & \multirow{4}{*}{$\begin{array}{c}\text { Banka } \\
\text { Türü }\end{array}$} & Mevduat & 174 & 81,69 \\
\hline & Kadın & 107 & 50,23 & & Katılım & 18 & 8,45 \\
\hline & Toplam & 213 & 100,00 & & $\begin{array}{l}\text { Kalkınma ve } \\
\text { Yatırım }\end{array}$ & 21 & 9,86 \\
\hline \multirow{6}{*}{ Eğitim } & Lise & 7 & 3,29 & & Toplam & 213 & 100,00 \\
\hline & Ön Lisans & 9 & 4,23 & \multirow{3}{*}{$\begin{array}{l}\text { Banka } \\
\text { Statüsü }\end{array}$} & Kamu & 35 & 16,43 \\
\hline & Lisans & 152 & 71,36 & & Özel & 178 & 83,57 \\
\hline & Yüksek Lisans & 39 & 18,31 & & Toplam & 213 & 100,00 \\
\hline & Doktora & 6 & 2,82 & \multirow{4}{*}{$\begin{array}{c}\text { Bankan } \\
\text { in } \\
\text { Ana } \\
\text { Ortağı }\end{array}$} & Yerli & 84 & 39,44 \\
\hline & Toplam & 213 & 100,00 & & Yabanc1 & 99 & 46,48 \\
\hline \multirow{9}{*}{ Tecrübe } & $0-2$ y1l & 13 & 6,10 & & $\begin{array}{c}\text { Yerli ve Yabancı } \\
\text { Payı Eşit }\end{array}$ & 30 & 14,08 \\
\hline & $3-4$ yil & 37 & 17,37 & & Toplam & 213 & 100,00 \\
\hline & $5-6$ y1l & 22 & 10,33 & \multirow{14}{*}{ Bölüm } & Şube & 110 & 51,64 \\
\hline & $7-8 \mathrm{y} 11$ & 30 & 14,08 & & Satış & 35 & 16,43 \\
\hline & $9-10 \mathrm{y} 1 \mathrm{l}$ & 39 & 18,31 & & Operasyon & 21 & 9,86 \\
\hline & 11-12 y1l & 19 & 8,92 & & İç Denetim & 11 & 5,16 \\
\hline & $13-14$ y1l & 12 & 5,63 & & $\begin{array}{l}\text { Alternatif } \\
\text { Dağıtım } \\
\text { Kanalları }\end{array}$ & 7 & 3,29 \\
\hline & 15 yıl ve üzeri & 41 & 19,25 & & Tahsis & 7 & 3,29 \\
\hline & Toplam & 213 & 100,00 & & İç Kontrol & 6 & 2,82 \\
\hline \multirow{4}{*}{ Statü } & Üst yönetici & 17 & 7,98 & & Mali İşler & 4 & 1,88 \\
\hline & Ara yönetici & 89 & 41,78 & & BT & 2 & 0,94 \\
\hline & Personel & 107 & 50,23 & & Hazine & 2 & 0,94 \\
\hline & Toplam & 213 & 100,00 & & Risk Yönetimi & 2 & 0,94 \\
\hline \multirow{3}{*}{ Aktif Bankacılık } & Evet & 141 & 66,20 & & Uyum & 2 & 0,94 \\
\hline & Hayır & 72 & 33,80 & & Diğer & 4 & 1,88 \\
\hline & Toplam & 213 & 100,00 & & Toplam & 213 & 100,00 \\
\hline
\end{tabular}

Tablo 1'den görüleceği üzere, ankete katılanların büyük kısmı lisans mezunlarından, erkeklerden, özel ve ana ortağın yabancı olduğu bankalarda çalışanlardan, şubelerde görev yapanlardan ve yönetici niteliği olmayan personelden oluşmaktadır. Ayrıca katılımcıların \%66,20'si aktif olarak bankacılık yapmaya devam etmektedir.

Katılımcıların son 1 yıl içinde psikolojik tacize maruz kalıp kalmadıkları incelenmiş̧ir. Tablo 2'de yer verildiği üzere, toplam katılımcıların \%90,6'sı son 1 yıl içinde psikolojik tacize maruz kalmıştır. Bu rakam katılımcıların büyük bir kısmının yakın zamanda psikolojik tacize maruz kaldıklarını göstermesi açısından önem taşımaktadır.

Tablo 2. Son 1 Yilda Psikolojik Tacize Maruz Kalma Durumu

\begin{tabular}{|c|c|c|}
\hline Seçenek & Frekans & \% \\
\hline Evet & 193 & 90,61 \\
\hline Hayır & 20 & 9,39 \\
\hline Toplam & 213 & 100,00 \\
\hline
\end{tabular}

Diğer taraftan 160 katılımcının psikolojik tacize neden olan hususlara yönelik sorulara verdikleri yanıtların dağıllımına Tablo 3'de yer verilmiştir. 
Tablo 3. Psikolojik Tacize Neden Olan Hususlar

\begin{tabular}{|l|c|c|c|}
\hline \multicolumn{1}{|c|}{ Detay } & $\begin{array}{c}\text { Tamamen } \\
\text { Katılıyorum }\end{array}$ & Katılıyorum & \% \\
\hline Kişilerin benlikleri & 130 & 26 & 97,50 \\
\hline Kişilerin güç gösterme çabası & 122 & 32 & 96,25 \\
\hline Kişilerin makam-mevki korkusu & 112 & 34 & 91,25 \\
\hline Psikolojik taciz uygulayan kişinin özgüven eksikliği & 97 & 35 & 82,50 \\
\hline $\begin{array}{l}\text { Psikolojik taciz uygulayan kişinin teknik anlamda yetersiz } \\
\text { olması ve bunu kabullenmemesi }\end{array}$ & 71 & 43 & 71,25 \\
\hline Ülkedeki yüksek işsizlik & 73 & 34 & 66,88 \\
\hline $\begin{array}{l}\text { Psikolojik taciz uygulayan kişinin herhangi bir konuda } \\
\text { karşıdakine özenmesi }\end{array}$ & 52 & 38 & 56,25 \\
\hline Bankanın yeterince kurumsallaşmaması & 47 & 41 & 55,00 \\
\hline
\end{tabular}

160 katılımcının \%97,50'si kişilerin benliklerinin, \%96,25'i güç gösterme çabalarının, \%91,25'i ise makam-mevki korkularının psikolojik tacize neden olduklarını belirtmişlerdir. İşsizliğin psikolojik tacize neden olduğunu düşünenlerin oranı ise \%66,88 olup bu husus dikkate değer bulunmuştur. Psikolojik tacize maruz kalanların reaksiyonlarına Tablo 4'de yer verilmiştir.

Tablo 4. Psikolojik Tacizin Sonuçları

\begin{tabular}{|l|c|c|}
\hline \multicolumn{1}{|c|}{ Psikolojik Tacizin Sonucu } & Frekans & \% \\
\hline Şikâyet etmedim aynı şekilde çalışmaya devam ettim & 81 & 50,63 \\
\hline Şikâyet etmedim ve çalışmayı bıraktım & 24 & 15,00 \\
\hline Şikâyet etmedim ve işten ayrıldım/başka firmaya geçtim & 16 & 10,00 \\
\hline Şikâyet ettim ama hiçbir şey değişmedi & 36 & 22,50 \\
\hline Şikâyet ettim ve psikolojik tacizi uygulayan kişi disiplin cezası aldı & 2 & 1,25 \\
\hline Şikâyet ettim ve psikolojik tacizi uygulayan kişinin işine son verildi & 1 & 0,63 \\
\hline Toplam & 160 & 100,00 \\
\hline
\end{tabular}

160 katılımcının \%50'si şikâyet etmeden çalışmaya devam ettiğini, \%22,50'si şikâyet ettiğini ancak herhangi bir değişiklik olmadığını belirtmişlerdir. Katılımcıların \%15'i şikâyet etmeyip işi bıraktığını, \%10'u ise şikâyet etmeyip başka bir şirkete geçtiklerini ifade etmişlerdir.

\section{3. Çalış̧manın İstatiksel Analizi ve Sonuçlar}

\subsubsection{Cronbach Alfa Testi}

Anket sonuçları için öncelikle verilen yanıtların iç tutarlığının yani ölçekteki sorular için verilen yanıtların homojen bir yapıda olup olmadığının ölçülmesi gerekmektedir. Bu amaç doğrultusunda Cronbach Alfa istatistiği hesaplanmıştır. Cronbach Alfa bir ölçekteki soruların varyansları toplamının genel varyansa oranlanması ile elde edilir ve 0 ile 1 arasında bir değer almaktadır. Bu katsayıya bağlı olarak ölçeğin iç tutarlılığı şu şekilde gösterilmektedir (Kalaycı, 2009):

- " $0,00 \leq(\alpha)<0.40$ ise ölçek güvenilir değildir.

- $0.40 \leq(\alpha)<0.60$ ise ölçeğin güvenilirliği düşüktür.

- $0.60 \leq(\alpha)<0.80$ ise ölçek oldukça güvenilirdir.

- $\quad 0.80 \leq(\alpha)<1.00$ ise ölçek yüksek derecede güvenilirdir".

Araştırmada sorgulanan tüm sorular için ve oluşması muhtemel alt gruplar için Cronbach Alfa katsayısı ile iç tutarlılık hesaplanmıştır (Cronbach, 1951). Hesaplanan katsayılara Tablo 5'de yer verilmiştir.

Tablo 5. Cronbach Alfa Katsayısı

\begin{tabular}{|l|c|c|c|}
\hline \multicolumn{1}{|c|}{ Bölüm } & $\begin{array}{c}\text { İfade } \\
\text { Sayısı }\end{array}$ & $\begin{array}{c}\text { Cronbach } \\
\text { Alpha }\end{array}$ & $\begin{array}{c}\text { İç Tutarlılı̆̆ı Zayıflatan İfadeler } \\
\text { Silindiğinde } \\
\text { Cronbach Alpha }\end{array}$ \\
\hline Genel & 27 & 0,794 & 0,807 \\
\hline Psikolojik Tacize Neden Olan Hususlar & 8 & 0,658 & 0,712 \\
\hline Psikolojik Tacizin İșe Etkileri & 6 & 0,843 & - \\
\hline Psikolojik Tacizin Iş Dışı Etkileri & 7 & 0,881 & 0,885 \\
\hline Psikolojik Tacizle Mücadele & 6 & 0,763 & 0,792 \\
\hline
\end{tabular}


Kartal, M., T., Depren, Ö., Kılıç Depren, S. / Journal of Yasar University, 2019, 14/54, 180-195

Cronbach Alfa testi sonucunda psikolojik tacize neden olan hususlar ile ilgi soruların Cronbach Alfa değeri 0,658; psikolojik tacizin işe etkileri ile ilgili sorularının Cronbach Alfa değeri 0,843; psikolojik tacizin iş dışı etkileri ile ilgili sorularının Cronbach Alfa değeri ise 0,881 ve son olarak psikolojik tacizle mücadele ile ilgili soruların Cronbach Alfa değeri 0,763 olarak elde edilmiştir. Söz konusu sonuçlar iç tutarlılığın yüksek olduğunu göstermektedir.

\subsubsection{Faktör Analizi}

Araştırmada psikolojik tacizle ilgili sorulan 26 adet ifade için Faktör Analizi uygulanarak kavramsal anlamlılığa ulaşılabilecek daha az sayıda faktör oluşturulmaya çalışılmıştır. Faktör Analizinin uygulanabilmesi için temel iki varsayımın sağlanması gerekmektedir; KMO ve Bartlett Küresellik testi. KMO test istatistiği için istenilen değerin 0,50'nin üzerinde olması gerektiği aksi takdirde değişkenlerin faktörleştirilemeyeceği ileri sürülmektedir. Bartlett Küresellik testinde ise $\mathrm{H}_{0}$ hipotezinin ret edilmesi faktör analizine devam edebilmek için gerekli bir durumdur (Çokluk vd., 2012).

Çalışmamızda kullandığımız anket verilerine ilişkin Kaiser-Meyer-Olkin (KMO) değeri 0.678, Bartlett's küresellik testi önemlilik değeri ise 0.000 olarak belirlenmiştir. Söz konusu sonuçlar anket verilerinin faktör analizine uygun olduğunu göstermektedir. Rotasyonsuz ve Varimax rotasyonu uygulanan Faktör Analizi sonucunda toplam varyans açıklama oranlarına Tablo 6'da yer verilmiştir.

Tablo 6. Faktör Analizi Tüm Sorular için Toplam Varyans Açıklama Oranı

\begin{tabular}{|c|c|c|c|c|c|c|c|c|c|}
\hline \multirow{2}{*}{ 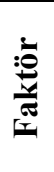 } & \multicolumn{3}{|c|}{ Özdeğerler } & \multicolumn{3}{|c|}{$\begin{array}{c}\text { Kareli Yükler } \\
\text { Toplamının Çıkarımı }\end{array}$} & \multicolumn{3}{|c|}{$\begin{array}{c}\text { Kareli Yükler } \\
\text { Toplamının Rotasyonu }\end{array}$} \\
\hline & Toplam & $\begin{array}{c}\text { Varyans } \\
\%\end{array}$ & $\underset{\%}{\text { Kümülatif }}$ & Toplam & $\begin{array}{c}\text { Varyans } \\
\%\end{array}$ & Kümülatif & Toplam & $\begin{array}{c}\text { Varyans } \\
\%\end{array}$ & Kümülatif \\
\hline 1 & 6,276 & 23,246 & 23,246 & 6,276 & 23,246 & 23,246 & 3,817 & 14,139 & 14,139 \\
\hline 2 & 3,282 & 12,155 & 35,402 & 3,282 & 12,155 & 35,402 & 3,284 & 12,163 & 26,301 \\
\hline 3 & 2,818 & 10,436 & 45,838 & 2,818 & 10,436 & 45,838 & 3,164 & 11,718 & 38,019 \\
\hline 4 & 1,737 & 6,433 & 52,271 & 1,737 & 6,433 & 52,271 & 2,389 & 8,847 & 46,865 \\
\hline 5 & 1,431 & 5,299 & 57,570 & 1,431 & 5,299 & 57,570 & 2,042 & 7,565 & 54,430 \\
\hline 6 & 1,205 & 4,464 & 62,034 & 1,205 & 4,464 & 62,034 & 1,595 & 5,907 & 60,337 \\
\hline 7 & 1,146 & 4,244 & 66,277 & 1,146 & 4,244 & 66,277 & 1,320 & 4,887 & 65,224 \\
\hline 8 & 1,136 & 4,208 & 70,485 & 1,136 & 4,208 & 70,485 & 1,235 & 4,574 & 69,798 \\
\hline 9 & 1,021 & 3,780 & 74,265 & 1,021 & 3,780 & 74,265 & 1,206 & 4,467 & 74,265 \\
\hline
\end{tabular}

Analiz sonucuna göre lamda değeri 1'den büyük olan 9 boyut olduğu görülmüştür ve bu 9 boyutun toplam varyans açıklama oranı \% 74,27'dir. Hangi maddelerin hangi boyutlarda toplandığına Tablo 7 'de yer verilmiştir.

Tablo 7. Faktör Analizi Tüm Sorular için Faktör Yükleri

\begin{tabular}{|l|c|c|c|c|c|c|c|c|c|}
\hline \multicolumn{1}{|c|}{ İfadeler } & \multicolumn{10}{|c|}{ Faktörler } \\
\cline { 2 - 10 } & $\mathbf{1}$ & $\mathbf{2}$ & $\mathbf{3}$ & $\mathbf{4}$ & $\mathbf{5}$ & $\mathbf{6}$ & $\mathbf{7}$ & $\mathbf{8}$ & $\mathbf{9}$ \\
\hline $\begin{array}{l}\text { Sosyal hayatımda sorunlar } \\
\text { yaşyorum }\end{array}$ &, 746 &, 251 &, 005 &, 015 &,- 147 &, 284 &, 039 &,- 003 &,- 050 \\
\hline Kendime güvenim azalıyor &, 828 &, 083 &,- 056 &,- 071 &, 094 &, 003 &,- 244 &, 142 &, 039 \\
\hline $\begin{array}{l}\text { Kendimi toplum içinde } \\
\text { değersiz görüyyorum }\end{array}$ &, 849 &, 046 &,- 035 &, 012 &, 077 &,- 018 &,- 071 &, 096 &,- 070 \\
\hline $\begin{array}{l}\text { Aile hayatımda sorunlar } \\
\text { yaşyorum }\end{array}$ &, 683 &, 198 &,- 048 &, 213 &,- 011 &, 183 &, 285 &,- 044 &, 109 \\
\hline Hayattan keyif almiyorum &, 758 &, 343 &, 003 &, 123 &,- 058 &, 008 &, 101 &,- 144 &, 059 \\
\hline İşe gelmek istemiyorum &, 159 &, 692 &,- 013 &, 006 &,- 026 &,- 152 &, 282 &, 394 &, 016 \\
\hline $\begin{array}{l}\text { İşte kendimi yorgun } \\
\text { hissediyorum }\end{array}$ &,- 017 &, 627 &,- 247 &, 070 &,- 198 &, 405 &,- 070 &,- 090 &, 311 \\
\hline $\begin{array}{l}\text { İş̧e konsantre olamiyorum } \\
\text { İşe yönelik motivasyonum } \\
\text { düşüyor }\end{array}$ &, 190 &, 721 &, 008 &, 097 &, 182 &, 230 &, 063 &, 021 &,- 052 \\
\hline $\begin{array}{l}\text { İşyerinde kendimi mutsuz } \\
\text { hissediyorum }\end{array}$ &, 393 &, 727 &,- 092 &, 009 &, 276 &, 250 &,- 090 &,- 108 &,- 207 \\
\hline $\begin{array}{l}\text { İşyerinde kendimi değersiz } \\
\text { hissediyorum }\end{array}$ &, 320 &, 616 &,- 081 &, 207 &, 232 &,- 066 &,- 081 &, 165 &, 164 \\
\hline
\end{tabular}


Kartal, M., T., Depren, Ö., Kılıç Depren, S. / Journal of Yasar University, 2019, 14/54, 180-195

\begin{tabular}{|c|c|c|c|c|c|c|c|c|c|}
\hline \multirow{2}{*}{ İfadeler } & \multicolumn{9}{|c|}{ Faktörler } \\
\hline & 1 & 2 & 3 & 4 & 5 & 6 & 7 & 8 & 9 \\
\hline $\begin{array}{l}\text { Psikolojik taciz bildirimi } \\
\text { yaptığımda banka misillemeye } \\
\text { karşı beni korumaktadır }\end{array}$ &, 001 &,- 045 &, 852 &, 033 &,- 041 &,- 122 & ,071 &,- 093 & ,006 \\
\hline $\begin{array}{l}\text { Psikolojik taciz bildirimi } \\
\text { yaptığımda banka ivedilikle } \\
\text { konuyla ilgilenmektedir }\end{array}$ &,- 030 &,- 048 &, 889 &, 090 &,- 031 &,- 118 & ,092 &,- 072 &,- 064 \\
\hline $\begin{array}{l}\text { Banka içi ve dışı iletişim } \\
\text { kanallarını gönül rahatlığ ile } \\
\text { kullanabilirim }\end{array}$ &,- 100 &,- 136 &, 776 &,- 152 &,- 025 &,- 092 &,- 014 &, 061 & , 158 \\
\hline $\begin{array}{l}\text { Banka psikolojik tacizin } \\
\text { önlenmesine ilişkin oldukça } \\
\text { hassas davranmaktadır }\end{array}$ &, 010 & ,003 &, 789 &, 075 &,- 002 &, 251 &,- 098 &, 126 & ,063 \\
\hline $\begin{array}{l}\text { Psikolojik taciz uygulayan } \\
\text { kişinin özgüven eksikliği }\end{array}$ & ,022 & ,058 &, 036 &, 804 &, 260 &, 105 &,- 144 & ,006 & ,099 \\
\hline $\begin{array}{l}\text { Psikolojik taciz uygulayan } \\
\text { kişinin herhangi bir konuda } \\
\text { karşıdakine özenmesi }\end{array}$ & ,037 & ,038 &, 046 &, 751 &, 170 &, 034 &, 126 &, 122 &, 054 \\
\hline $\begin{array}{l}\text { Psikolojik taciz uygulayan } \\
\text { kişinin teknik anlamda yetersiz } \\
\text { olması ve bunu } \\
\text { kabullenmemesi }\end{array}$ & ,091 & ,076 &,- 023 & ,903 &, 055 &, 002 & ,088 & ,046 &,- 038 \\
\hline Kişilerin benlikleri &,- 043 & ,134 &,- 063 & ,259 & 877 &, 171 & 053 & 071 & ,070 \\
\hline Kişilerin güç gösterme çabası & ,031 & , 156 &,- 021 &, 253 & 892 & ,033 & 053 & ,035 & ,133 \\
\hline Uyku sorunları yaşıyorum & ,480 & ,313 &,- 047 & ,036 & ,107 & ,524 & ,210 &,- 086 & ,189 \\
\hline S1klıkla baş ağrıları yaşıyorum &, 275 & ,191 &,- 143 &, 154 & ,266 &, 716 &, 133 & ,079 &,- 009 \\
\hline $\begin{array}{l}\text { Psikolojik taciz bildirimi } \\
\text { yapacağımda iş güvencemden } \\
\text { şüphe duymam }\end{array}$ &,- 034 &,- 073 &, 453 &,- 010 &, 034 & ,471 &,- 369 &, 309 &,- 108 \\
\hline Ülkedeki yüksek işsizlik &,- 023 & 006 &, 050 & ,067 & ,086 & ,086 & ,882 & ,061 &,- 097 \\
\hline $\begin{array}{l}\text { Bankanın yeterince } \\
\text { kurumsallaşmamas1 }\end{array}$ & ,035 & ,034 &, 017 &, 160 &, 081 &, 065 &, 034 & ,894 & ,033 \\
\hline $\begin{array}{l}\text { Kişilerin makam-mevki } \\
\text { korkusu }\end{array}$ & ,274 & ,023 &,- 059 & ,006 &, 187 &,- 015 &,- 026 &, 013 & ,669 \\
\hline
\end{tabular}

Tablo 7'de elde edilen sonuçlara göre, ülkedeki yüksek işsizlik, bankanın yeterince kurumsallaşmaması ve kişilerin makam-mevki korkusu ifadelerinin tek başlarına birer faktör oluşturduğu görülmüştür. Bu sebeple sözü geçen ifadeler analizden çıkartılarak Faktör Analizi tekrarlanmıştır. Bu prosedür sonucunda, lamda değeri 1'den büyük olan 6 boyut olduğu görülmüştür ve bu 6 boyutun toplam varyans açıklama oranı \%69,25'tir. Tablo 8 'de toplam varyans açıklama oranlarına yer verilmiştir.

Tablo 8. Faktör Analizi Değişiklikler Sonrası Toplam Varyans Açıklama Oranı

\begin{tabular}{|c|c|c|c|c|c|c|c|c|c|}
\hline \multirow{2}{*}{ 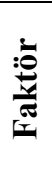 } & \multicolumn{3}{|c|}{ Özdeğerler } & \multicolumn{3}{|c|}{$\begin{array}{c}\text { Kareli Yükler } \\
\text { Toplamının Çıkarımı }\end{array}$} & \multicolumn{3}{|c|}{$\begin{array}{c}\text { Kareli Yükler } \\
\text { Toplamının Rotasyonu }\end{array}$} \\
\hline & Toplam & $\begin{array}{c}\text { Varyans } \\
\%\end{array}$ & Kümülatif \% & Toplam & $\begin{array}{c}\text { Varyans } \\
\%\end{array}$ & Kümülatif\% & Toplam & $\begin{array}{c}\text { Varyans } \\
\%\end{array}$ & Kümülatif\% \\
\hline 1 & 6,209 & 26,994 & 26,994 & 6,209 & 26,994 & 26,994 & 3,633 & 15,795 & 15,795 \\
\hline 2 & 2,921 & 12,699 & 39,693 & 2,921 & 12,699 & 39,693 & 3,028 & 13,167 & 28,961 \\
\hline 3 & 2,759 & 11,994 & 51,688 & 2,759 & 11,994 & 51,688 & 2,883 & 12,535 & 41,497 \\
\hline 4 & 1,711 & 7,441 & 59,129 & 1,711 & 7,441 & 59,129 & 2,380 & 10,346 & 51,843 \\
\hline 5 & 1,250 & 5,436 & 64,565 & 1,250 & 5,436 & 64,565 & 2,088 & 9,078 & 60,921 \\
\hline 6 & 1,078 & 4,685 & 69,250 & 1,078 & 4,685 & 69,250 & 1,916 & 8,328 & 69,250 \\
\hline
\end{tabular}

Tablo 9'da hangi maddelerin hangi boyutlarda toplandığı ve oluşturulan faktörler için kavramsal anlamlılık sonucunda faktörlere verilen isimler yer almaktadır. 
Kartal, M., T., Depren, Ö., Kılıç Depren, S. / Journal of Yasar University, 2019, 14/54, 180-195

Tablo 9. Faktör Analizi Değişiklikler Sonrası Faktör Yükleri

\begin{tabular}{|c|c|c|c|c|c|c|c|}
\hline \multirow{2}{*}{$\begin{array}{l}\text { Faktör } \\
\text { İsimleri }\end{array}$} & \multirow{2}{*}{ İfadeler } & \multicolumn{6}{|c|}{ Faktörler } \\
\hline & & 1 & 2 & 3 & 4 & 5 & 6 \\
\hline \multirow{5}{*}{$\begin{array}{l}\text { Psikolojik } \\
\text { Tacizin Sosyal } \\
\text { Hayata Etkisi }\end{array}$} & Sosyal hayatımda sorunlar yaşıyorum & 0,73 & 0,22 & 0,01 & 0,01 & 0,14 & 0,32 \\
\hline & Kendime güvenim azalıyor & 0,83 & 0,08 & 0,05 & 0,10 & 0,15 & 0,03 \\
\hline & Kendimi toplum içinde değersiz görüyorum & 0,84 & 0,07 & 0,04 & 0,01 & 0,09 & 0,01 \\
\hline & Aile hayatımda sorunlar yaşıyorum & 0,68 & 0,20 & 0,04 & 0,24 & 0,01 & 0,25 \\
\hline & Hayattan keyif almıyorum & 0,75 & 0,36 & 0,01 & 0,13 & 0,07 & 0,08 \\
\hline \multirow{5}{*}{$\begin{array}{l}\text { Psikolojik } \\
\text { Tacizin İş } \\
\text { Hayatına } \\
\text { Etkisi }\end{array}$} & İşe gelmek istemiyorum & 0,15 & 0,75 & 0,00 & 0,06 & 0,00 & 0,05 \\
\hline & İşe konsantre olamıyorum & 0,15 & 0,67 & 0,02 & 0,09 & 0,17 & 0,38 \\
\hline & İşe yönelik motivasyonum düşüyor & 0,02 & 0,66 & 0,10 & 0,02 & 0,22 & 0,38 \\
\hline & İşyerinde kendimi mutsuz hissediyorum & 0,37 & 0,75 & 0,09 & 0,03 & 0,04 & 0,05 \\
\hline & İşyerinde kendimi değersiz hissediyorum & 0,32 & 0,63 & 0,08 & 0,19 & 0,29 & 0,02 \\
\hline \multirow{4}{*}{$\begin{array}{l}\text { Bankanın } \\
\text { Psikolojik } \\
\text { Tacize } \\
\text { Yaklaşımı }\end{array}$} & $\begin{array}{l}\text { Psikolojik taciz bildirimi yaptığımda banka } \\
\text { misillemeye karşı beni korumaktadır }\end{array}$ & 0,01 & 0,04 & 0,86 & 0,03 & 0,07 & 0,09 \\
\hline & $\begin{array}{l}\text { Psikolojik taciz bildirimi yaptığımda banka } \\
\text { ivedilikle konuyla ilgilenmektedir }\end{array}$ & 0,04 & 0,03 & 0,89 & 0,10 & 0,07 & 0,12 \\
\hline & $\begin{array}{l}\text { Banka içi ve dışı iletişim kanallarını gönül } \\
\text { rahatlığı ile kullanabilirim }\end{array}$ & 0,09 & 0,13 & 0,79 & 0,15 & 0,01 & 0,11 \\
\hline & $\begin{array}{l}\text { Banka psikolojik tacizin önlenmesine ilişkin } \\
\text { oldukça hassas davranmaktadır }\end{array}$ & 0,02 & 0,01 & 0,79 & 0,08 & 0,04 & 0,13 \\
\hline \multirow{3}{*}{$\begin{array}{l}\text { Psikolojik } \\
\text { Taciz } \\
\text { Uygulayan } \\
\text { Kişinin } \\
\text { Davranışı }\end{array}$} & $\begin{array}{l}\text { Psikolojik taciz uygulayan kişinin özgüven } \\
\text { eksikliği }\end{array}$ & 0,01 & 0,01 & 0,05 & 0,77 & 0,28 & 0,16 \\
\hline & $\begin{array}{l}\text { Psikolojik taciz uygulayan kişinin herhangi } \\
\text { bir konuda karşıdakine özenmesi }\end{array}$ & 0,04 & 0,06 & 0,05 & 0,77 & 0,18 & 0,02 \\
\hline & $\begin{array}{l}\text { Psikolojik taciz uygulayan kişinin teknik } \\
\text { anlamda yetersiz olması ve bunu } \\
\text { kabullenmemesi }\end{array}$ & 0,08 & 0,09 & 0,03 & 0,91 & 0,03 & 0,02 \\
\hline \multirow{3}{*}{$\begin{array}{l}\text { Benlik ve Güç } \\
\text { Gösterme } \\
\text { Çabası }\end{array}$} & Kişilerin benlikleri & 0,07 & 0,12 & 0,06 & 0,28 & 0,86 & 0,17 \\
\hline & Kişilerin güç gösterme çabas1 & 0,01 & 0,16 & 0,02 & 0,27 & 0,89 & 0,06 \\
\hline & Kişilerin makam-mevki korkusu & 0,30 & 0,01 & 0,01 & 0,00 & 0,34 & 0,04 \\
\hline \multirow{3}{*}{$\begin{array}{l}\text { Psikolojik } \\
\text { Tacizin } \\
\text { Sağlığa Etkisi }\end{array}$} & İşte kendimi yorgun hissediyorum & 0,02 & 0,51 & 0,22 & 0,04 & 0,13 & 0,56 \\
\hline & Uyku sorunları yaşıyorum & 0,46 & 0,22 & 0,00 & 0,05 & 0,13 & 0,65 \\
\hline & Sıklıkla baş ağrıları yaşıyorum & 0,25 & 0,07 & 0,09 & 0,16 & 0,27 & 0,78 \\
\hline
\end{tabular}

Kavramsal anlamlılığı bozan ifadeler analizden çıkarıldığında psikolojik tacizle ilgili ifadelerin 6 faktörde toplandığı görülmüştür. Faktörlerin içindeki ifadelere detaylı olarak bakıldığında faktörler sırasıyla Psikolojik Tacizin Sosyal Hayata Etkisi, Psikolojik Tacizin İş Hayatına Etkisi, Bankanın Psikolojik Tacize Yaklaşımı, Psikolojik Taciz Uygulayan Kişinin Davranışı, Benlik ve Güç Gösterme Çabası, Psikolojik Tacizin Sağlığa Etkisi olarak isimlendirilmiştir. Soru formunda temelde 4 boyuta ayrılan bu ifadeler için aslında psikolojik tacizin iş dışı etkileri tek faktör değil, Psikolojik Tacizin Sağlığa Etkisi ve Psikolojik Tacizin Sosyal Hayata Etkisi olmak üzere iki alt faktörden oluştuğu gözlemlenmiştir. Benzer şekilde, Psikolojik Tacize neden olan hususlar da temelde Psikolojik Taciz Uygulayan Kişinin Davranışı ve Benlik/Güç Gösterme Çabası olmak üzere iki alt faktörden oluşmaktadır.

İsimlendirilen 6 faktör içindeki en büyük etkiye sahip ifadeler aşağıdaki gibidir:

> Psikolojik Tacizin Sosyal Hayata Etkisi için; Kendimi toplum içinde değersiz görüyorum,

$>$ Psikolojik Tacizin İş Hayatına Etkisi için; İşe gelmek istemiyorum,

> Bankanın Psikolojik Tacize Yaklaşımı için; Psikolojik Taciz bildirimi yaptığımda banka ivedilikle konuyla ilgilenmektedir,

> Psikolojik Taciz Uygulayan Kişinin Davranışı için; Psikolojik Taciz uygulayan kişinin teknik anlamda yetersiz olması ve bunu kabullenmemesi,

> Benlik ve Güç Gösterme Çabası için; Kişilerin güç gösterme çabası,

> Psikolojik Tacizin Sağlığa Etkisi için; Sıklıkla baş ağrıları yaşıyorum. 


\subsubsection{Faktör Regresyon Modeli}

Çalışmanın bu bölümünde, faktör analizi ile elde edilen ve kavramsal anlamlılığa sahip 6 faktörün psikolojik taciz uygulayan kişi ile mücadele edebilme gücü üzerindeki etkisi Lojistik Regresyon Modeli ile incelenmiştir. Faktör Analizi sonucunda elde edilen faktörler bağımsız değişkenler, soru formundaki psikolojik taciz uygulayan kişi ile mücadele edebilme gücü ile ilgili ifade ise bağımlı değişken olarak belirlenmiştir. Bağımlı değişken verilen olumlu ve olumsuz yanıtlara göre yeniden kodlanmıştır: 0-Mücadele etme gücü bulamam, 1-Mücadele etme gücü bulurum. Faktör analizi sonrasında elde edilen 6 faktör kullanılarak oluşturulan lojistik regresyon analizinde test edilen hipotezler aşağıda verilmiştir. Tüm hipotezler \%95 güven düzeyinde test edilmiştir.

1) Psikolojik tacizin sosyal hayata etkisi ile ilgili hipotezler aşağıdaki gibi oluşturulmuştur:

H0: Psikolojik tacizin sosyal hayata etkisinin, bireylerin psikolojik tacizle mücadele etme gücü üzerinde anlamlı bir etkisi yoktur.

H1: Psikolojik tacizin sosyal hayata etkisinin, bireylerin psikolojik tacizle mücadele etme gücü üzerinde anlamlı bir etkisi vardır.

2) Psikolojik tacizin iş hayatına etkisi ile ilgili hipotezler aşağıdaki gibi oluşturulmuştur:

H0: Psikolojik tacizin iş hayatına etkisinin, bireylerin psikolojik tacizle mücadele etme gücü üzerinde anlamlı bir etkisi yoktur.

H1: Psikolojik tacizin iş hayatına etkisinin, bireylerin psikolojik tacizle mücadele etme gücü üzerinde anlamlı bir etkisi vardır.

3) Bankanın psikolojik tacize yaklaşımı ile ilgili hipotezler aşağıdaki gibi oluşturulmuştur:

H0: Bankanın psikolojik tacize yaklaşımının, bireylerin psikolojik tacizle mücadele etme gücü üzerinde anlamlı bir etkisi yoktur.

H1: Bankanın psikolojik tacize yaklaşımının, bireylerin psikolojik tacizle mücadele etme gücü üzerinde anlamlı bir etkisi vardır.

4) Psikolojik taciz uygulayan kişinin davranışı ile ilgili hipotezler aşağıdaki gibi oluşturulmuştur:

H0: Psikolojik taciz uygulayan kişinin davranışının, bireylerin psikolojik tacizle mücadele etme gücü üzerinde anlamlı bir etkisi yoktur.

H1: Psikolojik taciz uygulayan kişinin davranışının, bireylerin psikolojik tacizle mücadele etme gücü üzerinde anlamlı bir etkisi vardır.

5) Bireylerin güç gösterme çabası ile ilgili hipotezler aşağıdaki gibi oluşturulmuştur:

H0: Bireylerin güç gösterme çabasının, bireylerin psikolojik tacizle mücadele etme gücü üzerinde anlamlı bir etkisi yoktur.

H1: Bireylerin güç gösterme çabasının, bireylerin psikolojik tacizle mücadele etme gücü üzerinde anlamlı bir etkisi vardır.

6) Psikolojik tacizin sağlığa etkisi ile ilgili hipotezler aşağıdaki gibi oluşturulmuştur:

H0: Psikolojik tacizin sağlığa etkisinin, bireylerin psikolojik tacizle mücadele etme gücü üzerinde anlamlı bir etkisi yoktur.

H1: Psikolojik tacizin sağlığa etkisinin, bireylerin psikolojik tacizle mücadele etme gücü üzerinde anlamlı bir etkisi vardır.

Lojistik regresyon analizi sonucuna Tablo 10 'da yer verilmiştir.

Tablo 10. Lojistik Regresyon Çıktısı Beta Katsayıları ve Anlamlılık

\begin{tabular}{|l|c|c|c|}
\hline & $\boldsymbol{\beta}$ & $\boldsymbol{p}$ & $\boldsymbol{e}^{\boldsymbol{\beta}}$ \\
\hline Psikolojik Tacizin Sosyal Hayata Etkisi & $-0,573$ &, 018 &, 564 \\
\hline Psikolojik Tacizin İş Hayatına Etkisi & $-0,100$ &, 075 &, 905 \\
\hline Bankanın Psikolojik Tacize Yaklaşımı & 0,730 &, 003 & 2,076 \\
\hline Psikolojik Taciz Uygulayan Kişinin Davranışı & 0,529 &, 028 & 1,697 \\
\hline Benlik ve Güç Gösterme Çabası & 0,297 &, 048 & 1,345 \\
\hline Psikolojik Tacizin Sağlığa Etkisi &,- 026 &, 012 &, 974 \\
\hline Sabit Terim &,- 068 &, 067 &, 934 \\
\hline
\end{tabular}

Lojistik regresyon analizi sonucu, beklendiği üzere psikolojik tacizin bireylerin sosyal hayatına, iş hayatına ve sağlığına olan negatif etkisi attıkça bireylerin psikolojik tacizi uygulayan kişiye karş1 mücadele gücünün düştüğünü göstermiştir. Bankanın psikolojik tacize karşı koruyucu yaklaşımı, psikolojik taciz uygulayan kişinin teknik yetersizliği ve güç gösterme çabası ise psikolojik tacize uğrayan bireylerin bu kişi ile mücadele gücünü arttırdığı görülmektedir. Her faktörün psikolojik taciz uygulayan kişiyle mücadele gücü üzerindeki etki büyüklüğü incelendiğinde, etki büyüklüğü en yüksekten en düşüğe doğru sırasıyla Bankanın Psikolojik Tacize Yaklaşımı, Psikolojik Taciz Uygulayan Kişinin Davranışı, Benlik ve Güç Gösterme Çabası, Psikolojik Tacizin İş Hayatına Etkisi ve Psikolojik Tacizin Sağlığa Etkisidir. Buna göre, psikolojik tacizle mücadelede en büyük yükün bankaya düşmekte olduğu görülmektedir. Eğer bankanın psikolojik tacize yaklaşım şekli psikolojik tacize uğrayan çalışanın haklarını korumaya yönelik olması 
durumunda bireylerin de mücadele gücünün artacağı söylenebilir. Özellikle psikolojik taciz bildirimi yapıldığında bankanın vakit kaybetmeden konu ile ilgilenmesi gerekliliği ortaya çıkmaktadır. Psikolojik tacizin sosyal hayata etkisi de psikolojik tacizle mücadelede göz ardı edilemeyecek büyüklükte etkiye sahiptir. Özellikle faktör regresyon analizi sonucunda bireylerin psikolojik taciz sonrasında kendisini toplumda değersiz görme eğiliminde oldukları söylenebilir.

Elde edilen modele göre mücadele gücüne sahip olma durumu için doğru sınıflama oranı Tablo 11'de verilmiştir.

Tablo 11. Lojistik Regresyon Doğru Sınıflama Yüzdesi

\begin{tabular}{|l|l|c|c|c|}
\hline \multicolumn{2}{|c|}{} & \multicolumn{2}{|c|}{ Model Tahmini } & \multirow{2}{*}{ Toplam } \\
\cline { 3 - 4 } \multirow{3}{*}{ Gerçekleşen } & $\begin{array}{l}\text { Mücadele } \\
\text { Gücü Yok }\end{array}$ & $36(\% 72)$ & $14(\% 28)$ & $50(\% 100)$ \\
\cline { 2 - 4 } & $\begin{array}{l}\text { Mücadele } \\
\text { Gücü Var }\end{array}$ & $17(\% 36)$ & $30(\% 64)$ & $47(\% 100)$ \\
\hline \multicolumn{2}{|l|}{ Toplam } & 53 & 44 & 97 \\
\hline
\end{tabular}

Tablo 11'e göre modelin doğru sınıflama oranı mücadele gücü yok kategorisi için $\% 72$, mücadele gücü var kategorisi için ise \%64 olarak hesaplanmıştır. Genel olarak bakıldığında ise doğru sınıflama oranın [(36+30)/97]*100 = $\% 68$ olduğu görülmektedir. Mevcut oranlara bakıldığında doğru sınıflana oranlarının kabul edilebilir seviyelerde oldukları söylenebilir.

Bankalarda psikolojik tacizin önlenmesi için psikolojik taciz vakalarının yönetim kurulu bünyesinde oluşturulacak etik komiteler tarafindan ele alınması önerilmektedir. Bankalarda psikolojik taciz üst seviyede konumlandırılmış bir komite tarafından ele alınmazsa çalı̧̧anlar psikolojik tacize maruz kalmaya devam edecektir. Psikolojik taciz davaları nedeniyle bankalar finansal kayıplarla, yaptırımlarla ve dolayısı ile itibar riski ile karşı karşıya kalabilecektir.

\section{Sonuc}

Günümüzde iş hayatı geçmiş dönemlere kıyasla önemli ölçüde değişim ve dönüşüm geçirmektedir. Bu süreçte çalışanlar çeşitli zorluklarla karşı karşıya kalmaktadır. İş güvencesi, sosyal haklar gibi zorlukların yanı sıra çalışanların karşılaştı̆̆ önemli sorunların başında psikolojik taciz gelmektedir.

Psikolojik taciz, başta psikolojik tacize uğrayan çalışanlar olmak üzere diğer çalışanları, işyerlerini, aileleri ve toplumu olumsuz etkilemektedir. Ayrıca sorunlu ve gerilimli bir örgüt kültürü oluşmasına neden olmaktadır. Bu nedenlerle psikolojik taciz günümüz iş hayatında çalışanlar ve işverenler açısından en önemli hususlardan biri haline gelmiştir. Hatta kamu otoriteleri tarafindan psikolojik tacizin önlenmesi ile ilgili düzenlemeler yapılmıştır.

Son zamanlarda çeşitli sektörlerle ilgili olmasına karşın bankacılık sektöründe psikolojik tacizle ilgili basına anonim olarak yansıyan vakalarda artış görülmektedir. Bu nedenle Türk Bankacılık Sektöründe psikolojik tacizin anlaşılmasına ve araştııılmasına yönelik çalışmalar, başta psikolojik tacizden etkilenen çalışanlar, aileler, şirketler ve tüm toplum olmak üzere iş ve kurum kültürü açısından önem taşımaktadır. Bu nedenle bu çalışmada Türk Bankacılık Sektöründe psikolojik taciz incelenmiştir. Söz konusu amaca ulaşabilmek için bankalarda çalışan ve çalışıp ayrılmış olan 213 personele yönelik anket çalışması gerçekleştirilmiştir.

Araştırmada öncelikle katılımcılara farklı konularda 26 adet ifadeye ne derece katıldıkları sorgulanmıştır. Sonrasında verilen cevaplara göre ilgili ifadelerin doğal gruplarını tespit edebilmek amacıyla Açıklayıcı Faktör Analizi uygulanmış ve kavramsal anlamlılığı negatif olarak etkileyen ifadeler çıkartılmıştır. Sonuçta 23 adet ifade 6 faktör altında toplanmıştır. Bu faktörlerin toplam varyans açıklayıcılı̆̆ı kabul edilebilir sınırlar dâhilinde \%69,25 olarak hesaplanmıştır.

Araştırmanın ikinci bölümünde, açıklayıcı faktör analizi ile oluşturulan faktörler kullanılarak belirlenen faktörlerin psikolojik tacizle mücadele gücünü ne derece etkilediği incelenmiştir. Uygulanan lojistik regresyon sonucunda psikolojik tacizle mücadelede etkisi en yüksek olan faktörün bankanın psikolojik tacize yaklaşımı olduğu belirlenmişsir. $\mathrm{Bu}$ faktörün detayına bakıldığında, psikolojik taciz bildiriminde bankanın vakit kaybetmeden konu ile ilgilenmesi en öncelikli husus olarak görülmektedir. Araştırmadaki bir diğer dikkat çekici sonuç ise "Psikolojik taciz sonucunda ne oldu?" sorusuna verilen yanıtlarda görülmektedir. Psikolojik tacize uğrayan katılımcıların \%50'si şikâyet etmeden çalışmaya devam ettiğini, \%25'i şikâyet etmeyip işlerini bıraktı̆̆ ya da değiştirdiğini, \%23'ü ise şikâyet ettiğini fakat hiçbir aksiyon alınmadığını belirtmiştir. Araştırmadaki bu iki bulgudan hareketle, psikolojik tacizle mücadele için hem çalışanların yaşadıklarını doğru ve zamanında ilgili mercilere aktarması hem de bankanın gerekli ve yeterli yaptırımı uygulayacak prosedürleri hayata geçirmesi gerekmektedir.

Diğer taraftan ülkedeki işsizliğin psikolojik tacize neden olan unsurlardan biri olması, psikolojik tacizle mücadelede rol alması beklenen iç denetim ve iç kontrol bölümlerinde psikolojik taciz yaşanması ve psikolojik tacizin en yoğun olarak şubelerde ve satış bölümlerinde yaşandığının belirlenmesi çalışmanın önemli sonuçlarındandır. Katılımcıların da \%66 oran ile belirttiği üzere, başta bankalar olmak üzere psikolojik tacizin tüm işyerlerinde önlenebilmesi ülkede \%10-12 seviyesinde bulunan işsizliğin azaltılması önem taşımaktadır. Türkiye'de işsizliğin yüksek olması bazı işverenler ve yöneticiler tarafından çalışanlara karşı psikolojik taciz uygulanmasında bir faktör olarak kullanılabilmektedir. Bu durumda ise psikolojik taciz vakaları yaşanmaya devam edecektir. 
Kartal, M., T., Depren, Ö., Kılıç Depren, S. / Journal of Yasar University, 2019, 14/54, 180-195

Bankalarda psikolojik tacizin önlenmesi için psikolojik taciz vakalarının yönetim kurulu bünyesinde oluşturulacak etik komiteler tarafından ele alınması önerilmektedir. Bankalarda psikolojik taciz üst seviyede konumlandırılmış bir komite tarafından ele alınmazsa çalışanlar psikolojik tacize maruz kalmaya devam edecek, bankalar psikolojik taciz davaları nedeniyle finansal kayıplarla, yaptırımlarla ve dolayısıyla itibar riski ile karşı karşıya kalabilecektir.

Çalışmamızda tespit edilen hususlar psikolojik tacizin önlenmesine yönelik aksiyon alınmasında bankalara yol gösterici olacak ve bir rehber özelliği taşıyacaktır. Düzenlemelere tam uyum sağlanması ve çalışanlara yönelik psikolojik tacizin önlenmesi için belirtilen hususlarda bankaların önleyici aksiyonlar alması yerinde olacaktır.

213 anket katılımcısı ile Türk Bankacılık Sektöründe psikolojik tacizle ilgili yaptı̆̆ımız bu araştırmanının yanı sıra daha geniş katılımlı araştırma çalışmalarında daha farklı sonuçlara ulaşılabileceği dikkate alındığında sonraki dönemlerde daha geniş katılımlı çalışmaların yapılması önerilmektedir. 
Kartal, M., T., Depren, Ö., Kılıç Depren, S. / Journal of Yasar University, 2019, 14/54, 180-195

\section{KAYNAKÇA}

ACAS. (2018), Bullying and harassment at work-guidance for employees, http://www.acas.org.uk/CHttpHandler.ashx?id=306\&p=0, Erişim tarihi: 19.06.2018.

Akpınar, E. N. (2016). Öğretmenlerin mobbing algısının çeşitli değişkenler açısından incelenmesi. Elektronik Sosyal Bilimler Dergisi, 15(56), 295-308.

Aldığg, E. (2011), İş yerinde yıldırma (mobbing) ve örnek bir çalışma. Yayınlanmış Yüksek Lisans Tezi, Doğuş Üniversitesi Sosyal Bilimler Enstitüsü, İstanbul.

Altuntaş, C. (2010). Mobbing kavramı ve örnekleri üzerine uygulamalı bir çalışma. Journal of Yaşar University, 18(5), 2995-3015

Atman, Ü. (2012). İşyerinde psikolojik terör: Mobbing. Sağlıkta Performans ve Kalite Dergisi, (3), 157-174.

Başbakanlık (2011), İşyerlerinde psikolojik tacizin (mobbing) önlenmesi. 2011/2 Sayılı Genelge, 19.03.2011 tarihli ve 27879 sayılı Resmi Gazetede yayınlanmış.

Bayram, S. (2011). Psikolojik taciz (mobbing) ve başbakanlık genelgesi. Mali Çözüm, 104, 317-325.

Bedük, A. ve Yıldız, E. (2016). Mobbing (psikolojik şiddet) ve örgütsel bağlılık ilișkisi: Hastane çalışanlarına yönelik bir uygulama. KMÜ Sosyal ve Ekonomik Araştırmalar Dergisi, 18(31), 77-87.

Bozbel, S. ve Palaz, S. (2007). İşyerinde psikolojik taciz (mobbing) ve hukuki sonuçları. TíSK Akademi, 2(3), 66-81.

Brigitte, K. (2004). Cortisol day profiles in victims of mobbing. Journal of Psychosomatic Research, 56, 149-150.

Cemaloğlu, N. ve Ertürk, A. (2007). Öğretmenlerin maruz kaldıkları yıldırma eylemlerinin cinsiyet yönünden incelenmesi. Türk Eğitim Bilimleri Dergisi, 5(2), 345-362.

Cronbach, L. J. (1951). Coefficient alpha and the internal structure of tests. Psychometrika, 16 (3), 297-334.

Çokluk, Ö., Şekercioğlu, G. ve Büyüköztürk, Ş. (2012). Sosyal Bilimler Iç̧in Çok Değişkenli İstatistik: SPSS ve Lisrel Uygulamaları. Ankara: Pegem Akademi Yayınc1l1k.

Çukur, C. (2012). İşyerinde psikolojik taciz (mobbing). Çimento Endüstrisi İşverenleri Sendikası Dergisi, (2), 34-48.

Çukur, C. (2016). Türk Hukuku ve Karşılaştırmalı Hukukta İşyerinde Psikolojik Taciz. Yayın No: 9, Ankara: TBMM Araştırma Merkezi Yayınları.

Demir, Y. ve Çavuş, M. F. (2009). Mobbing'in kişisel ve örgütsel etkileri üzerine bir araştırma. Niğde Üniversitesi İ̈BF Dergisi, 2(1), 13-23.

Dündar, G. ve Acar, A. B. (2008). İşyerinde psikolojik yıldırmaya (mobbing) maruz kalma sıklığı ile demografik özellikler arasındaki ilişkinin incelenmesi. Ístanbul Üniversitesi İşletme Fakültesi Dergisi, 37(2), 111-120.

Erçetin, Ş. Ş., Hamedoğlu, M. A. ve Çelik, S. (2008). Mobbing in primary schools: A case study for Hendek Country. World Applied Sciences Journal, 3(6), 945-955.

Erdem, T. (2014). Mobbing ve mobbing ile mücadele yöntemleri. Türk Kütüphaneciliği, 28(4), 622-628.

Gökçe, A. T. (2009), Mobbing: İş yerinde yıldırma kavramsal çerçeve, http://www.universitetoplum.org/text.php3?id=393, Erişim tarihi: 11.04.2017.

Göktürk, G. Ş. ve Bulut, S. (2012). Mobbing: İşyerinde psikolojik taciz. Abant İzzet Baysal Üniversitesi Sosyal Bilimler Dergisi, 1(24), 53-70.

Güngör, M. (2008). Çalışma Hayatında Psikolojik Taciz. İstanbul: Derin Yayınları.

Güngör, S. K. ve Potuk, A. (2018). Öğretmenlerin mobbing, örgütsel adalet ve örgütsel sessizlik algıları ve aralarındaki ilişki. Hacettepe Üniversitesi Eğitim Fakültesi Dergisi, 33(3), 723-742.

Güzel, A. ve Ertan, E. (2007). İşyerinde psikolojik tacize (mobbing'e) hukuksal bakış: Avrupa hukuku ve karşılaștırmalı hukuk. Legal İş Hukuku ve Sosyal Güvenlik Hukuku Dergisi, 14, 510-549.

Kalaycı, Ş. (2009). SPSS uygulamalı çok değişkenli istatistik teknikleri. Ankara: Asil Yayın Dağıtım.

Karahan, A. ve Yılmaz, H. (2014). Mobbing ve örgütsel bağlılık ilişkisine yönelik bir çalışma. Journal of Yaşar University, 9(33), 5692-5715.

Karcıoğlu, F. ve Akbaş, S. (2010). İşyerinde psikolojik şiddet ve iş tatmini ilişkisi. Atatürk Üniversitesi IIIBF Dergisi, 24(3), 139-161.

Kaygın, E. ve Atay, M. (2014). Mobbing'in örgütsel güven ve örgütsel sessizliğe etkisi-Kamu kurumunda bir uygulama. Çukurova Üniversitesi İktisadi ve İdari Bilimler Fakültesi Dergisi, 18(2), 95-113.

Kök, S. B. (2006). İş yaşamında psiko-şiddet sarmalı olarak yıldırma olgusu ve nedenleri. 14. Ulusal Yönetim ve Organizasyon Kongresi, 25-27 Mayıs, Atatürk Üniversitesi İIBF.

Leymann, H. (1996). The content and development of mobbing at work. European Journal of Work and Organizational Psychology, 5(2), 165-184.

Mercanlığlu, Ç. (2010). Çalışma hayatında psikolojik tacizin (mobbing) nedenleri, sonuçları ve Türkiye'deki hukuksal gelişimi. Organizasyon ve Yönetim Bilimleri Dergisi, 2(2), 37-46.

Mizrahi, R. (2013). Çalışma hayatında mobbing ile mücadele yöntemleri. Sosyal ve Beşeri Bilimler Dergisi, 5(2), 443452.

Özen, S. (2007). İşyerinde psikolojik şiddet ve nedenleri. $\dot{I}_{S ̧}$, Güç Endüstri İlişkileri ve İnsan Kaynakları Dergisi, 9(3), $1-24$.

Özkul, B. ve Çarıkçı, İ. H. (2010). Mobbing ve Türk hukuku açısından değerlendirilmesi. Süleyman Demirel Üniversitesi İ̈BF Dergisi, 15(1), 481-499. 
Kartal, M., T., Depren, Ö., Kılıç Depren, S. / Journal of Yasar University, 2019, 14/54, 180-195

Palaz, S., Özkan, S., Sarı, N., Göze, F., Şahin, N. ve Akkurt, Ö. (2008). İş yerinde psikolojik taciz (mobbing) davranışları üzerine bir araştırma: Bandırma örneği. İ̧̧ Güç, Endüstri İliş̧kileri ve İnsan Kaynakları Dergisi, 10(4), 41-58.

Pehlivan, M. (2015). Bireysel ayrılıklar ve toplumsal dezavantajlar çerçevesinde İşyerinde psikolojik taciz: Mobbing. MAKÜ İktisadi ve Ídari Bilimler Fakültesi Dergisi, 2 (2), 65-78.

Poirier, G., Rivest, R. ve Frechette, H. (2018), The new standards for protection against psychological harassment in the workplace: A modern day approach, http://www.cnt.gouv.qc.ca/fileadmin/pdf/publications/yb_psycho_CNTeng_.pdf, Erişim tarihi: 20.04.2018.

Savaş, F. B. (2007). İsyerinde Manevi Taciz. İstanbul: Beta Basım.

Seçkin, Z. ve Demirel, Y. (2014). Çalışanların örgütsel adalet algıları ile psikolojik yıldırma davranışı (mobbing) arasındaki ilişki. Atatürk Üniversitesi Sosyal Bilimler Enstitüsü Dergisi, 18(1), 329-348.

Sheehan, M. (2004). Workplace mobbing: A proactive response. Workplace Mobbing Conference, 1-11, 14-15 October, Australia.

Şahin, S. ve Türk, M. (2010). Çalışanlarda psikolojik şiddet algılaması ve kadın çalışanlar üzerine bir araştırma. Çukurova Üniversitesi İ̈BF Dergisi, 14(2), 1-9.

Şimşek, A. S. (2013). Mobbing kaderimiz midir? Barış Araştırmaları ve Çatışma Çözümleri Dergisi, 1(2), 36-45.

Taşkın, A. (2015). İşyerinde mobbing'in ceza hukuku bakımından değerlendirilmesi. Çalışma ve Toplum, 2015/1, 221257.

Temizel, Y. (2013). Mobbing ve Türk hukuk sistemindeki yeri. Adalet Dergisi, 45, 188-223.

Tetik, S. (2010). Mobbing kavramı: Birey ve örgütler açısından önemi. KMÜ Sosyal ve Ekonomik Araştırmalar Dergisi, 12(18), 81-89.

Tınaz, P. (2006). Mobbing: İşyerinde psikolojik taciz. Çalışma ve Toplum, 3, 11-22.

Turaç, İ. S. ve Şahin, B. (2014). Mobbing'e maruz kalma durumunun belirlenmesi: Hemşireler üzerine bir çalışma. Eskişehir Osmangazi Üniversitesi Sosyal Bilimler Dergisi, 15(1), 87-112.

Tutar, H. (2004). İşyerinde psikolojik şiddet sarmalı: Nedenleri ve sonuçları. Yönetim Bilimleri Dergisi, 2(2), $101-128$.

Yamada, D. (2018), Workplace bullying and The law: A report from the United States. The Japan institute for labour policy and training, workplace bullying and harassment report, http://www.jil.go.jp/english/reports/documents/jilpt-reports/no.12_u.s.a..pdf, Erişim tarihi: 20.06.2018.

Yücetürk, E. E. (2012). İşyerlerindeki yıldırma eylemlerini önlenmede sendikaların rolü: Nitel bir araştırma, Çalışma ve Toplum, 4(35), 41-72. 
Ek 1. Anket Soruları

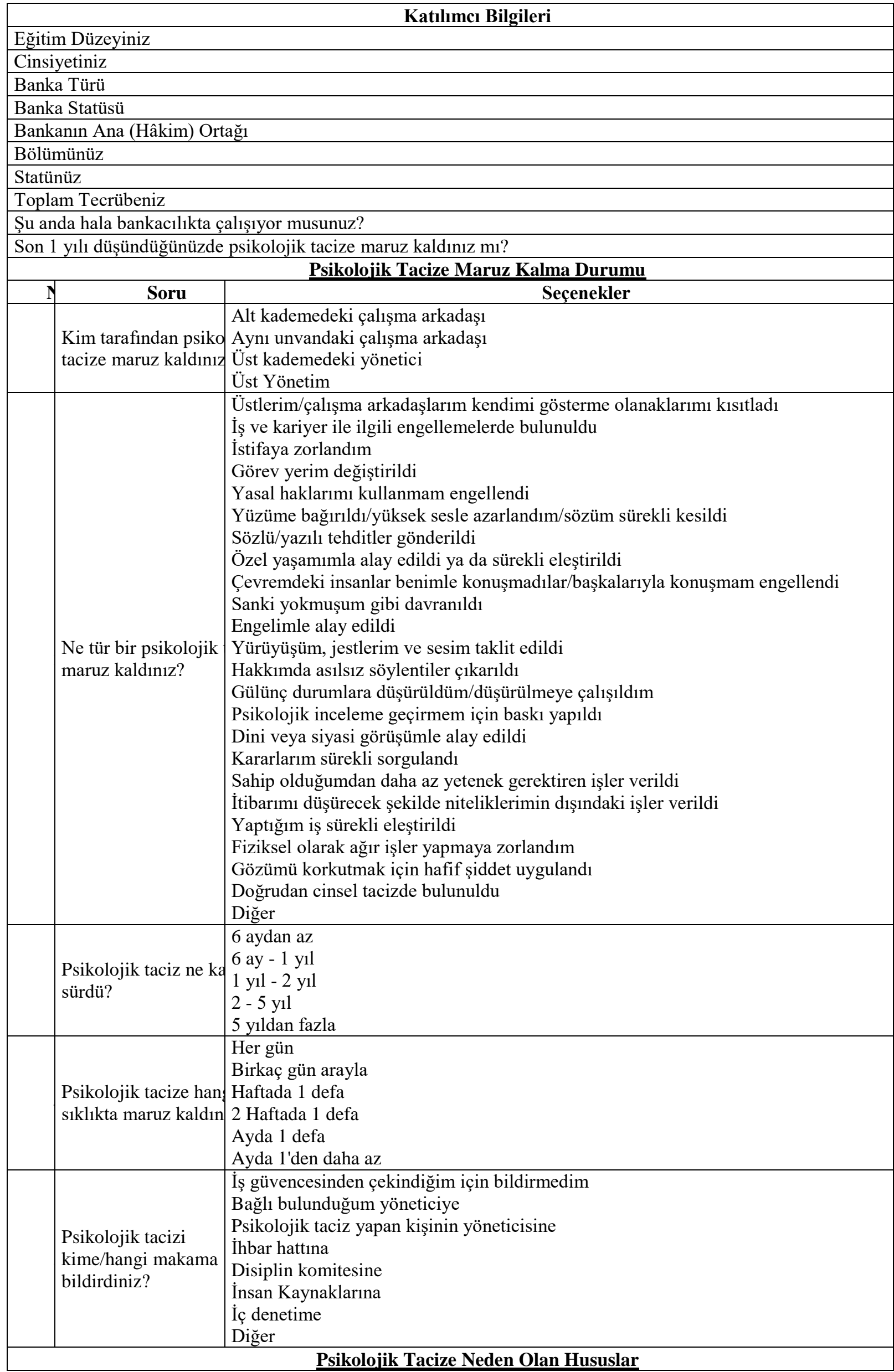


Kartal, M., T., Depren, Ö., Kılıç Depren, S. / Journal of Yasar University, 2019, 14/54, 180-195

\begin{tabular}{|c|}
\hline Ülkedeki yüksek işsizlik \\
\hline Bankanın yeterince kurumsallaşmaması \\
\hline Kişilerin benlikleri \\
\hline Kişilerin güç gösterme çabası \\
\hline Kişilerin makam-mevki korkusu \\
\hline Psikolojik taciz uygulayan kişinin özgüven eksikliği \\
\hline Psikolojik taciz uygulayan kişinin herhangi bir konuda karşıdakine özenmesi \\
\hline Psikolojik taciz uygulayan kişinin teknik anlamda yetersiz olması ve bunu kabullenmemesi \\
\hline Psikolojik Tacizin İșe Etkileri \\
\hline İşe gelmek istemiyorum \\
\hline İşte kendimi yorgun hissediyorum \\
\hline İşe konsantre olamıyorum \\
\hline İşe yönelik motivasyonum düşüyor \\
\hline İşyerinde kendimi mutsuz hissediyorum \\
\hline İşyerinde kendimi değersiz hissediyorum \\
\hline Psikolojik Tacizin İs Dıșı Etkileri \\
\hline Sosyal hayatımda sorunlar yaşıyorum \\
\hline Uyku sorunları yaşıyorum \\
\hline Sıklıkla baş ağrıları yaşıyorum \\
\hline Kendime güvenim azalıyor \\
\hline Kendimi toplum içinde değersiz görüyorum \\
\hline Aile hayatımda sorunlar yaşıyorum \\
\hline Hayattan keyif almiyorum \\
\hline Psikolojik Tacizle Mücadele \\
\hline Psikolojik tacizi bildirebileceğim banka içi telefon/e-posta hattı bulunmaktadır \\
\hline Psikolojik tacize karşı ALO170 hattının bulunduğunu biliyorum \\
\hline Bankada psikolojik taciz şikâyetlerini ele alan üst düzey bir komite/kurul bulunmaktadır \\
\hline Psikolojik taciz bildirimi yaptığımda banka misillemeye karşı beni korumaktadır \\
\hline Psikolojik taciz bildirimi yaptığımda banka ivedilikle konuyla ilgilenmektedir \\
\hline Banka içi ve dış1 iletişim kanallarını gönül rahatlığı ile kullanabilirim \\
\hline Psikolojik taciz bildirimi yapacağımda iş güvencemden şüphe duymam \\
\hline Banka Psikolojik tacizin önlenmesine ilişkin oldukça hassas davranmaktadır \\
\hline $\begin{array}{l}\text { Psikolojik taciz uygulayan kişi ile mücadele edecek (ilgili makama bildirecek, hukuki yollara başvuracak vb } \\
\text { gücü kendimde bulurum }\end{array}$ \\
\hline Psikolojik Taciz Sonucunda Ne Oldu? \\
\hline Şikâyet etmedim aynı şekilde çalışmaya devam ettim \\
\hline Şikâyet etmedim ve işten ayrıldım/başka firmaya geçtim \\
\hline Şikâyet etmedim ve çalışmayı bıraktım \\
\hline Şikâyet ettim ama hiçbir şey değişmedi \\
\hline Şikâyet ettim ve Psikolojik tacizi uygulayan kişi disiplin cezası aldı \\
\hline Şikâyet ettim ve Psikolojik tacizi uygulayan kişinin işine son verildi \\
\hline Kariyer Tercihine Etki \\
\hline Bankada Psikolojik tacize maruz kalmanız/şahit olmanız performansınızı düşürür mü? \\
\hline Bankada Psikolojik tacize maruz kalmanız/şahit olmanız bankaya bağlılığınızı azaltır mı? \\
\hline $\begin{array}{l}\text { Bankada Psikolojik tacize maruz kalmanız/şahit olmanız kariyer değişikliği/iş değişikliği yapmanıza neden } \\
\text { mu? }\end{array}$ \\
\hline
\end{tabular}

